\title{
Effect of Micronutrints on Growth, Vigour and Fruit Weight of Nagpur Mandarin (Citrus reticulate Blanco) in Satpura Plateau Region, India
}

\author{
Uttam Soni $^{1 *}$, Bhupendra Thakre ${ }^{2}$ and Omnarayan Verma ${ }^{1}$ \\ ${ }^{1}$ Department of Agronomy, ${ }^{2}$ Department of Plant Pathology, Zonal Agricultural Research \\ Station, JNKVV, Chhindwara, MP 480001, India \\ *Corresponding author
}

\section{A B S T R A C T}

Keywords

Citrus, Foliar

Spray,

Micronutrients,

Fruit retention.

Article Info

Accepted:

04 June 2017

Available Online:

10 August 2017
Micro nutrient play important role for better growth, Vigour flowering and fruiting in citrus tree. Micronutrient deficiency is wide spread in the existing orchards. In this investigation, effect of micro nutrients on growth, vigor and fruit weight of Nagpur Mandarin (Citrus reticulate Blanco) in Satpura Plateau. Experiments were conducted in Jawaharlal Nehru Krishi Vishwa Vidyalaya, Zonal Agriculture Research Station, Mohagaon Farm, Sausar Block of Chhindwara District of Madhya Pradesh during 2015 with varying in soil properties and agro-climatic conditions. Plants at both sites were subjected to foliar spray. The spray was applied twice: once at pea stage and gravel stage. There were 15 treatments for foliar spray of $\mathrm{Zn}, \mathrm{Cu}, \mathrm{Fe}$ and $\mathrm{Mo}$ in combinations. Foliar application of $\mathrm{CuSo}_{4}$ (0.4\% Spray) at pea stage and gravel stage increased the fruit retention to the extent of $46 \%$ as compared to control $23 \%$ only.

\section{Introduction}

Citrus fruits are commercially important since pre- independence period in India. In central India mainly Viddarbha region of Maharashtra and adjoining parts of Madhya Pradesh, Nagpur Mandarin (Citrus reticulate Blanco), an easily peel able orange locally called as "Santra" is commercially grown since last 100 years. Records of cultivation of this mandarin in this region are available from late nineteenth century as well. Nagpur Mandarin is famous world over for its fine flover that develops in agro- climatic condition of central India especially in Vidarbha and adjoining Chhindwara region of Madhya Pradesh.
The nutrition constitutes an important component of successful and healthy citrus cultivation. An inadequate nutrition leads to the improper growth and reduced productivity of the citrus trees. The mineral nutrients are composed of major and micro- nutrients. Among the major nutrients, $\mathrm{N}, \mathrm{P}$ and $\mathrm{K}$ are the primary nutrients and are required in large amount while, $\mathrm{Ca}, \mathrm{Mg}$ and $\mathrm{S}$ are the secondary nutrients and most of them are supplied to the trees along with the primary nutrients through the synthetic fertilizers (Singh and Khan 2012).The micronutrients on the other hand though are required in small amount but play a great role in plant metabolism (Katyal, 2004; Kazi et al., 2012). 
These are involved in the synthesis of many compounds essential for plant growth and productivity and are the activators for various enzymes. For instance, $\mathrm{Zn}$ is involved in the biosynthesis of Tryptophan, a precursor of naturally occurring auxin, indole acetic acid (IAA) (Swietlik, 2002), Mn is required in the process of photosynthesis (Mengel and Kirkby, 1987) and Fe plays a key role in several enzyme-systems, in which haeme or haemin is the prosthetic group (Khurshid et al., 2008). The main sources of micronutrients are parent material, sewage sludge, fungicides, farmyard manure and also present in small amount in soil (Nafees, 2009; Awad and Romheld, 1993). Micronutrients deficiency is common in peach orchards and fruit trees in Peshawar (Tariq, 2008). Soil and climatic factors affecting the availability of micronutrients including: $\mathrm{pH}$, soil water content, organic matter, nutrients interaction, temperature and light. The DTPA and ABDTPA extractable $\mathrm{Zn}, \mathrm{Cu}$, and $\mathrm{Fe}$ decreases with increasing soil pH (Khattak, 1994). Soil test is of limited value for orchards where roots penetrate 1-2 $\mathrm{m}$ in the soil and samples are taken from surface soil $(30 \mathrm{~cm})$ in most cases and do not represent the fertility status of the lower depths where the roots are feeding. Therefore, plant analysis is commonly accepted as being the most reliable guide for evaluating the success of the orchard's fertility program (Basar, 2006). However, the micronutrients content in the leaves usually does not indicate the status of micronutrients in plant (Abadia, 2000; Razeto and Valdes, 2006).

\section{Materials and Methods}

A field study was conducted on Jawaharlal Nehru Krishi Vishwa Vidyalaya, Zonal Agriculture Research Station, Mohagaon Farm, Sausar Block of Chhindwara District of Madhya Pradesh during 2015-16. Twenty Five trees were selected for the trial. Each tree was considered as an individual treatment in the experiment. 15 treatments with four replications were applied. The spray was applied twice: once at pea stage and gravel stage with object of experiment effect of micro nutrients on growth, Vigor and fruit weight of Nagpur Mandarin (Citrus reticulate Blanco) in Satpura Plateau Region. There were 15 treatments for foliar spray of $\mathrm{Zn}, \mathrm{Cu}$, Fe \& Mo in combinations as per detailed as, $\mathrm{ZnSO}_{4}\left(0.4 \%\right.$ Spray); $\mathrm{ZnSO}_{4}(0.5 \%$ Spray), A/M (0.05 \% Spray), A/M (0.1 \% Spray) $\mathrm{FeSO}_{4}\left(0.4 \%\right.$ Spray), $\mathrm{FeSO}_{4}(0.5 \%$ Spray), $\mathrm{CuSO}_{4} \quad(0.4 \quad \% \quad$ Spray $), \mathrm{CuSO}_{4} \quad(0.5 \%$ Spray), $\mathrm{ZnSO}_{4}(0.4 \%$ Spray $)+\mathrm{A} / \mathrm{M}(0.05 \%$ Spray), $\mathrm{FeSO}_{4}(0.4 \%$ Spray $)+\mathrm{A} / \mathrm{M}(0.05 \%$ Spray), $\mathrm{CuSO}_{4}(0.4 \%$ Spray $)+\mathrm{A} / \mathrm{M}(0.05 \%$ Spray), $\mathrm{ZnSO}_{4}(0.4 \%$ Spray $)+\mathrm{CuSO}_{4}(0.4 \%$ Spray), $\mathrm{ZnSO}_{4}(0.4 \%$ Spray $)+\mathrm{FeSO}_{4}(0.4 \%$ Spray), $\mathrm{CuSO}_{4}(0.4 \%$ Spray $)+\mathrm{FeSO}_{4}(0.4 \%$ Spray) and Control. The experiment was laid out in randomized block design and replicated thrice. Foliar applications were given during the months of March and April. Statistical Analysis Data were subjected to analysis of variance and differences among treatments evaluated through Statistics 8.1.

\section{Results and Discussion}

Foliar application of micronutrients $(\mathrm{Zn}, \mathrm{Cu}$, $\mathrm{Fe} \& \mathrm{Mo}$ ) significantly affected on the growth, Vigor and fruit weight of Nagpur Mandarin which showed increasing trend with increase in levels of micronutrients with few exceptions (Table 1).

The data were statistically analyzed and significant difference is observed on fruit retention due to micronutrients $\mathrm{CuSO}_{4}(0.5 \%$ Spray) application at pea stage and gravel stage recorded the highest $46.28 \%$ fruit retention while $\mathrm{FeSO}_{4}(0.5 \%$ Spray) and $\mathrm{CuSO}_{4}$ (0.4\% Spray) + Ammonium Molybdate (0.05\% Spray) recorded 39.54 and $36.81 \%$ retention respectively. In control retention to is 23.37 percent only. 
Table.1 Effect of different micronutrients on growth yield and fruit retention \% in Nagpur Mandarin

\begin{tabular}{|c|c|c|c|c|c|c|}
\hline S.No & Treatment & $\begin{array}{c}\text { Plant Height } \\
\text { cm }\end{array}$ & $\begin{array}{c}\text { Plant Spread } \\
\text { cm }\end{array}$ & $\begin{array}{c}\text { Plant Girth } \\
\text { cm }\end{array}$ & $\begin{array}{l}\text { Average of } 100 \\
\text { fruits/Tree } \mathrm{kg}\end{array}$ & $\begin{array}{c}\text { Fruit Retention } \\
\% \text { at Maturity }\end{array}$ \\
\hline 01 & $\mathrm{ZnSO}_{4}(0.4 \%$ Spray $)$ & 20.00 & 36.67 & 1.3 & 16.20 & 24.09 \\
\hline 02 & $\mathrm{ZnSO}_{4}(0.5 \%$ Spray $)$ & 20.00 & 23.33 & 1.0 & 16.33 & 33.05 \\
\hline 03 & A/M (0.05\% Spray) & 18.33 & 30.00 & 1.0 & 15.56 & 33.20 \\
\hline 04 & A/M (0.1 \% Spray) & 16.67 & 30.00 & 1.0 & 15.13 & 25.68 \\
\hline 05 & $\mathrm{FeSO}_{4}(0.4 \%$ Spray $)$ & 16.67 & 28.33 & 1.0 & 15.33 & 26.69 \\
\hline 06 & $\mathrm{FeSO}_{4}(0.5 \%$ Spray $)$ & 18.33 & 40.00 & 1.0 & 15.50 & 39.54 \\
\hline 07 & $\mathrm{CuSO}_{4}(0.4 \%$ Spray $)$ & 15.00 & 43.33 & 1.0 & 15.26 & 25.23 \\
\hline 08 & $\mathrm{CuSO}_{4}(0.5 \%$ Spray $)$ & 18.33 & 36.67 & 1.0 & 15.43 & 46.28 \\
\hline 09 & $\mathrm{ZnSO}_{4}(0.4 \%$ Spray $)+\mathrm{A} / \mathrm{M}(0.05 \%$ Spray $)$ & 16.67 & 35.00 & 1.0 & 15.10 & 36.28 \\
\hline 10 & $\mathrm{FeSO}_{4}(0.4 \%$ Spray $)+\mathrm{A} / \mathrm{M}(0.05 \%$ Spray $)$ & 18.33 & 40.00 & 1.3 & 15.50 & 29.55 \\
\hline 11 & $\mathrm{CuSO}_{4}(0.4 \%$ Spray $)+\mathrm{A} / \mathrm{M}(0.05 \%$ Spray $)$ & 16.67 & 23.33 & 1.0 & 15.30 & 36.81 \\
\hline 12 & $\mathrm{ZnSO}_{4}(0.4 \%$ Spray $)+\mathrm{CuSO}_{4}(0.4 \%$ Spray $)$ & 18.33 & 31.67 & 1.0 & 16.00 & 35.39 \\
\hline 13 & $\mathrm{ZnSO}_{4}(0.4 \%$ Spray $)+\mathrm{FeSO}_{4}(0.4 \%$ Spray $)$ & 16.67 & 35.00 & 1.3 & 16.90 & 34.80 \\
\hline 14 & $\mathrm{CuSO}_{4}(0.4 \%$ Spray $)+\mathrm{FeSO}_{4}(0.4 \%$ Spray $)$ & 16.67 & 36.67 & 1.0 & 15.33 & 29.13 \\
\hline 15 & Control & 20.33 & 33.33 & 1.0 & 15.50 & 23.37 \\
\hline & SEm_+ & 3.51 & 4.51 & 0.325 & 0.176 & 2.06 \\
\hline & C.D. at $5 \%$ & NS & NS & NS & NS & 5.95 \\
\hline & C.V. \% & 34.48 & 0.233 & 58.64 & 3.38 & 11.15 \\
\hline
\end{tabular}


Fig.1 Plant height $(\mathrm{cm})$, plant spread $(\mathrm{cm})$, plant girth $(\mathrm{cm})$ average weight of 100 fruits per tree $(\mathrm{kg})$ and fruit retention $\%$ at maturity

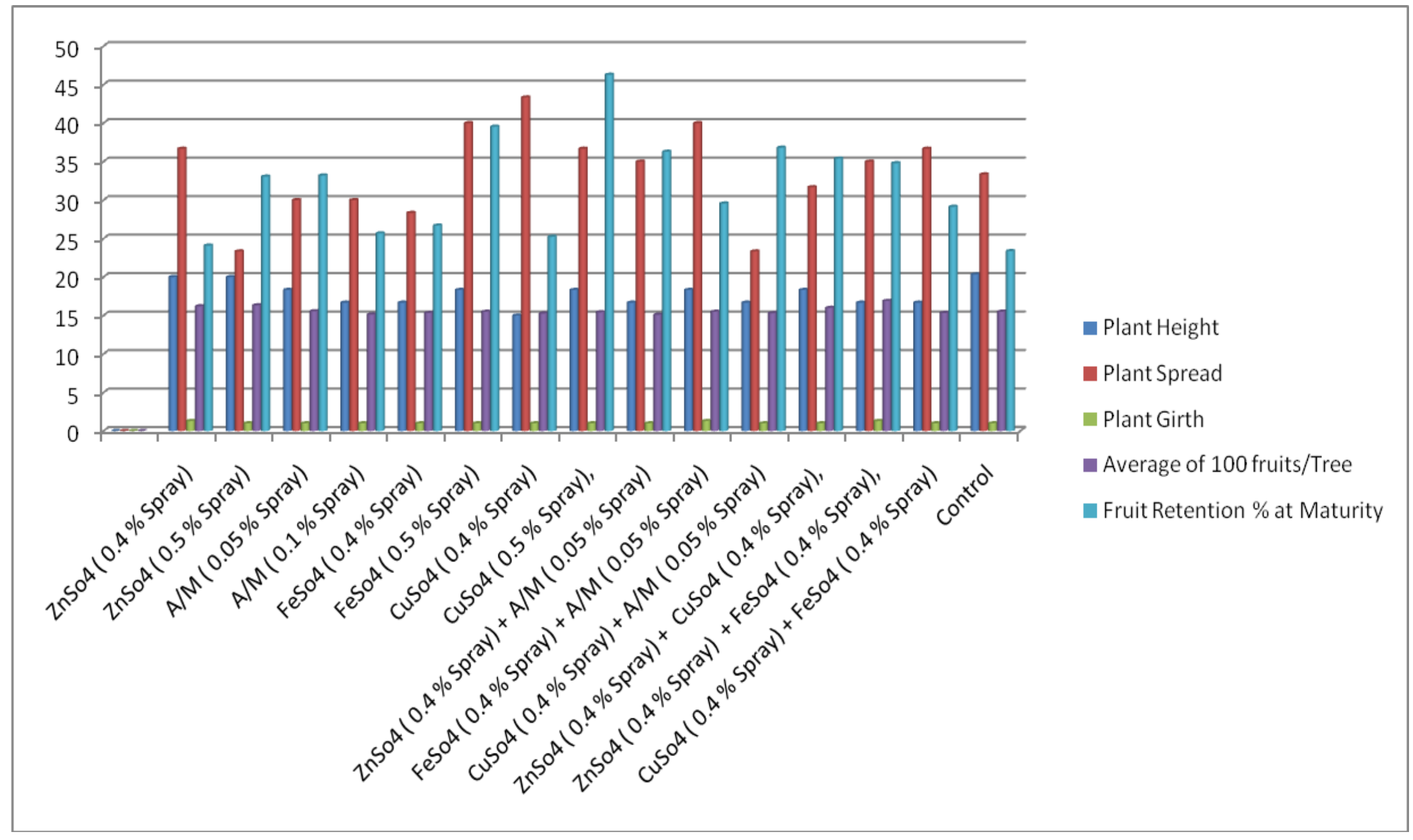


Fruit Retention Percent at Maturity the varied significantly by the application of micronutrients. Fruit Retention Percent at Maturity increased with the application of micronutrients and significantly higher (one tree / replication / Treatment) was obtained with the foliar application of micronutrients over control in $\mathrm{CuSO}_{4} \quad(0.5 \%$ Spray $)$ and flowed in combination of foliar application of $\mathrm{CuSO}_{4}(0.4$ $\%$ Spray) + Ammonium Molybdate (0.05\% Spray). However, maximum Average weight of 100 fruits per tree $(\mathrm{Kg})$ was obtained with the foliar application of $\mathrm{ZnSO}_{4}(0.5 \%$ Spray), $\mathrm{ZnSO}_{4}\left(0.4 \%\right.$ Spray) followed by $\mathrm{ZnSO}_{4}(0.4$ $\%$ Spray $)+\mathrm{FeSO}_{4}(0.4 \%$ Spray $)$.

Micro nutrient play important role for better growth, Vigour flowering and fruiting in citrus tree. Micronutrient deficiency is wide spread in the existing orchards. The concentration of micronutrients in the plant height $(\mathrm{cm})$, plant spread $(\mathrm{cm})$ plant girth $(\mathrm{cm})$ average weight of 100 fruits per tree $(\mathrm{Kg})$ and fruit retention \% at maturity revealed that whether the specific micronutrients are received or not. None of the micronutrient showed the same level in all treatments. But fruit retention \% at maturity and average weight of 100 fruits per tree $(\mathrm{kg})$ that the micronutrients were adequate in all the treatments after spray. These results showed that leaf analysis is a best tool for the evaluation of micronutrients in orchards.

In conclusion, Foliar application of $\mathrm{CuSO}_{4}$ $(0.4 \%$ spray) at pea stage and gravel stage increased the fruit retention to the extent of $46 \%$ as compared to control $23 \%$ only.

\section{Acknowledgement}

We are very thankful to Professor Dr. S.R.Dharpure (Ex - Associate Director Research / Coordinator TMC - Chhindwara) and Dr. D.N.Nandeker (Coordinator TMC Chhindwara) Jawaharlal Nehru Krishi Vishwa Vidyalaya, Zonal Agriculture Research Station, for their kind supervision and help in designing and executing the experiment.

\section{References}

Anonymous (2013). Area and production of fruit crops in India. Indian Hort. Database 2013. AOAC (1990). Official methods of Analysis. 10th edn. Washington DC, USA.

Chapmann, H.D. (1964). Suggested foliar sampling and handling technique for determining nutrient status of some field, horticultural and plantation crops. Indian J. Hort., 21:98-118.

Dixit, C.K., Yamdagni, R. and Jindal, P.C. (1977). A note on the effect of micronutrients spray on the quality of Kinnow - A mandarin hybrid. Haryana J. of Hort. Sci., 6(3-4):153-54.

Hassan, A.K. 1995. Effect of foliar spray with some micronutrients on Washington Navel orange tree, tree fruiting and quality. Annals Agr. Sci., 33(4): 15071516.

Humphries, E.C. 1956. Mineral composition and ash analysis. In: Modern methods of plant analysis. Vol. I (Eds.) K. Peach and M.V. Tracey, Springer-Verlag, Berlin. Pp. 468-502

Josan J. S. and Thatai S. K. (2008). Studies on the evaluation of rootstocks for Kinnow mandarin under North Indian conditions. Indian J Hort 65: 332-334.

Katyal, J.C. (2004). Role of micronutrients in ensuring opti-mum use of macronutrients. IFA International symposium on micronutrients, New Delhi, India pp 3-17.

Kaur, N., Monga, P.K., Arora, P.K. and Kumar, K. 2015. Effect of micronutrient on leaf composition, fruit quality and yield of Kinnow mandarin. J. Appl. Nat. Sci., 7(2): 639-643.

Kazi S.S., Syed Ismail and Joshi K.G. (2012). Effect of multi-micronutrient on yield and quality attributes of sweet orange. African J. of Agric. Res., 7(29): 4118-23

Labanwskas, C.K., Jones, W.W and Embrleton, T.W. 1963. Effect of foliar application of manganese zinc, and urea on yield and quality of valancencia orange and nutrient concentrations in the leaf, peel and juice. 
Proc. Amer. Soc. Hort. Sci., 82: 142-153.

Mann, M.S., Josan, J.S., Chohan, G.S and Vij, V.K. (1985). Effect of foliar application of micronutrients on leaf composition, fruit yield and quality of sweet orange cv. Blood Red. Indian J. Hort., 42 (1-2): 4549.

Nanaya, K.A., Anjaneylu, K. and Kotur, S.C. 1985. Effect of foliar applied $\mathrm{Zn}, \mathrm{Mn}, \mathrm{Cu}$ and $\mathrm{Mg}$ on growth parameters, chlorosis and interrelationships of micronutrients in leaf tissue of Coorg mandarin. Prog. Hort., 17: 309-314.

Obreza, T.A., Zekri, M., Hanlon, E.A., Morgan, K., Schumann, A. and Rouse, R. 2010. Soil and leaf tissue testing for commercial citrus production. University of Florida Extension Service SL 253. Pp: 04.

Rama, R.A. and Bose, T.K. (2000). Effect of foliar application of magnesium and micronutrients on growth, yield and quality of mandarin (Citrus reticulata Blanco). Indian J. of Hort., 57(3): 215-20.

Razzaq, K., Khan A.S., Malik A.U., Shahid M. and Ullah S. (2013). Foliar application of Zinc influences the leaf mineral status, vegetative and reproductive growth, yield and fruit quality of Kinnow mandarin. $J$ Plant Nutrition 36: 1479-1495.

Sarrwy, S.M.A., Mohamed, H. El-Sheikh, S. Sanaa Kabeil and Abdelaal Shamseldin (2012). Effect of foliar application of different potassium forms supported by zinc on leaf mineral contents, yield and fruit quality of "Balady" Mandrine trees. Middle-East Journal of Scientific Research, 12 (4): 490-498.

Sharma, K.K., Sharma K.N. and Nayyar V.K. (1990). The effect of copper and Zinc sprays on leaf nutrient concentration in Kinnow mandarin (Citrus reticulate $\mathrm{x}$ Citrus deliciosa). Indian J Hort., 60(4): 278-80.

Singh A., Naqvi S. A. M. H. and Singh S. (2003). Citrus germplasm, rootstocks and varieties. Kalyani Publishers, India.

Singh I.P. and Shyam Singh. (2006). Exploration, collection and characterization of citrus germplasm - a Review. Agric Rev 27 (2): 79-80.

Singh Z. and Khan A.S. (2012). Surfactant and nutrient uptake in citrus. In: Advances in Citrus Nutrition. Ed. Srivastava A.K. Springer Science \& Business Media. P 157-67.

Somasundaram, J., H.R. Meena, R.K. Singh, S.N. Prasad and A.K. Parandiyal. 2011. Diagnosis of micronutrient imbalance in lime crop in semi-arid region of Rajasthan, India. Communications Soil Sci. Plant Analysis, 42: 858-869.

Srivastava, A.K. and Singh S. 2003. Citrus Nutrition. 1st edition, International Book Distributing Co., Lucknow. Pp: 59.

Swietlik, D. 1999. Zinc nutrition in horticultural crops. In: J. Janick (Ed.). Horticultural Reviews. John Wiley \& Sons, Inc., pp. 109-118.

Swietlik, D. 2002. Zinc nutrition of fruit trees by foliar sprays. Acta Hort., Pp: 594.

Swietlik, D. (2002). Zinc nutrition of fruit trees by foliar sprays. Acta Hort., 594: 123129.

Taiz, L. and Zeiger, E. 1994. Plant Physiology, 2nd edn. Sinauer Associates, Inc., Publishers. Sunderland, Massachusetts, Pp: 104-113.

\section{How to cite this article:}

Uttam Soni, Bhupendra Thakre and Omnarayan Verma. 2017. Effect of Micronutrints on Growth, Vigour and Fruit Weight of Nagpur Mandarin (Citrus Reticulate Blanco) in Satpura Plateau Region, India. Int.J.Curr.Microbiol.App.Sci. 6(8): 435-440. doi: https://doi.org/10.20546/ijcmas.2017.608.057 